\title{
UNUSUAL NEST SITE OF COMMON CROW
}

by Robert W. Nero, Regina

On May 26, 1962, Ralph D. Carson, Bernard Haysom and I were greatly surprised to see a crow's nest built on a telephone pole close to a busy highway. This was a few miles west of Boharm, Saskatchewan, on transCanada highway \#1. The telephone pole, which supported a main trunk line, had four cross-arms and numerous wires. The nest was built on the second cross-arm from the top, adjacent to the pole, and was about 35 feet above the ground. It was about 100 feet north of the highway. We did not climb the pole to check the nest contents, but it was clear that it was an active nest; as we watched from the shoulder of the road one bird, probably a male, fed something to a second bird which was sitting on the nest. This nest site seemed particularly unusual because there were at least six groves of trees within a quarter of a mile. The nearest group of trees, which consisted of full-sized box elders (Manitoba maple) and willows, was only about 300 feet from the pole.

Bent's "Life histories of North American jays, crows and titmice" (Bulletin 191, 1946), gives several examples of unusual nest sites of crows, including nests on the ground, in emergent aquatics over water, and even on top of a chimney on a church near Lumsden. The latter record was contributed by Fred Bradshaw who recorded a number of unusual nest sites in the Canadian Field-Naturalist in 1930 (Vol. 44: 149-150). Bradshaw also reported that he found crows nesting on the cross-arms of telephone poles in treeless sections of the prairie, usually near marshes. The present observation of a nest on a telephone pole, near trees and in a relatively dry area, further proves the adaptability of the crow in it; choice of a nesting site.

\section{UNUSUAL NEST SITE OF SORA}

\section{by Thomas E. Randall, Edmonton}

On June 10, 1945, I discovered an unusual nest site of a Sora at a small pond at Brooks, Alberta. This pond was a shallow depression in the prairie, dotted with clumps of candle-rush and other coarse herbage and also holding several stalks of willow. The hollow had been inundated by the overflow of water from an irrigation ditch which was some 20 yards away. As I passed by the pond I heard the song of a Sora and decided to look for a nest. I quickly found one, containing 12 eggs, in a clump of rush. I continued my search but failed to find another nest until, as I passed one of the willow bushes, a Sora flew from near the top of the bush, which was about seven feet tall and made up of a dozen or more small stems. In the center of the bush I found a nest containing 10 eggs. It was compactly built of strips of cattail rush leaves which had been brought from the nearby ditch. It was four and one-half feet above the water which was about a foot in depti. The nest was tied to three will'w stems in the same way as is the nest of a Redwinged Blackbird.
Several days later I found that four more eggs had been laid and incubation was under way. I next saw the nest about three weeks later, and the young had hatched and left. It seemed to me that this was a most unusual place for a Sora to build its nest.

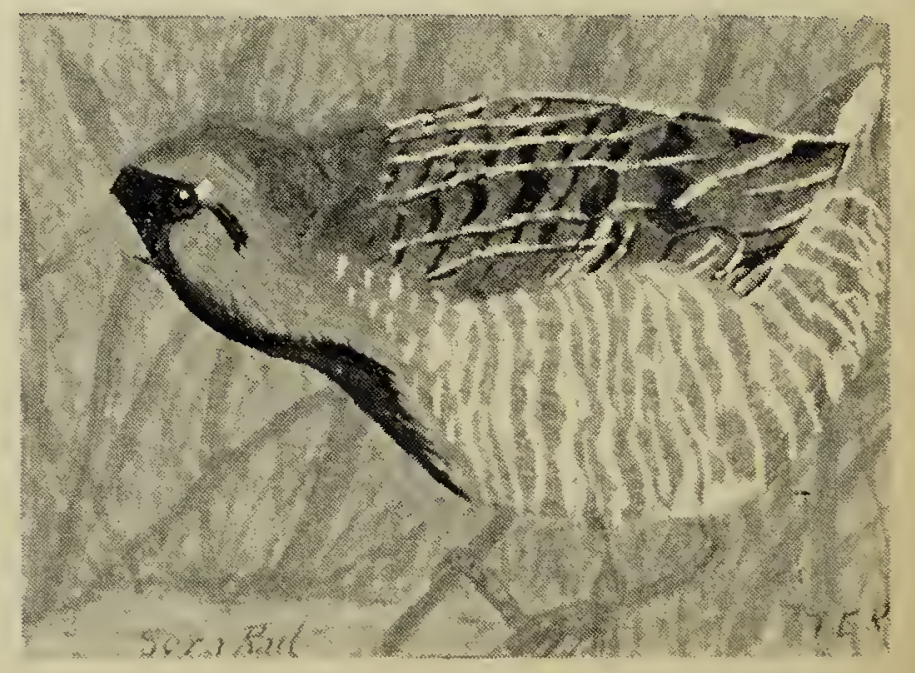

Drawing by T. E. Randall SORA RAIL 